\title{
Length-Weight Relationship of the Toothed Pony Fish, Gazza Minuta (Bloch, 1797) from Tuticorin Waters of India
}

\author{
S. Puvaneswari ${ }^{1 *}$, R. Karuppasamy ${ }^{2}$ \\ ${ }^{1,2}$ Department of Zoology, Annamalai University, Annamalai Nagar, Chidambaram Tamil Nadu India
}

Available online at: www.isroset.org

Received: 30/May/2019, Accepted: 15/Jun/2019, Online: 30/Jun/2019

\begin{abstract}
Length-weight analysis for specimen comprising 494 males, 515 females and indeterminants of Gazza minuta, collected from Tuticorin fish landing centre was made to assess the relationship between the variables The length-weight relationship was estimated using the exponential equation $\mathrm{W}=\mathrm{aL}^{\mathrm{n}}$ for one species of pony fish belonging to family leiognathidae, species Gazza minuta, in the catches of tuticorin landing centre. The correlation co-efficient ("r" values) of male, female and indeterminants were found to be $0.9750(\mathrm{p}<0.001), 0.9800(\mathrm{p}<0.001)$ and $0.8931(\mathrm{p}<0.001)$ respectively. Length-weight relationship study in G. minuta obeys cube law, particularly in the adults.
\end{abstract}

Keywords: Gazza minuta, indeterminants, exponential equation, Tuticorin fish

\section{INTRODUTION}

The application of scientific knowledge for the development of fishing industry lies in an intimate knowledge on the biology of fishes. Without full and proper information on the life history, Habits and behavior of fishes, it would not be possible to plan, control and manage the fishery resources in a satisfactory manner. Practically nothing is known about the biology of the vast number of pelagic species which contribute much to the pelagic fishery resources of the east coast. It is only within this objective, the present investigation is initiated to study the biology of Gazza minuta.

Reports on the biology of Gazza are available but are few and spotty [1] has reported the fishery of G. minuta. [2] Reported about G. shettyi. [3] Studied the osteology of G .minuta. [4] made some observation on G. achlamys. [5] Analyzed age and growth of G. minuta. [6] observed food and feeding habits and [7] reported on reproductive biology on porto nova waters. No work has been done so far regarding the biology of Gazza minuta along the Tuticorin coast. Hence the present work was undertaken to have detailed information about the biology of G. minuta along Tuticorin coast. The length-weight relationship studies (LWR) is an important tool in fish biology, physiology, ecology and fisheries assessment [8]. It can be used for converting lengths into biomass, determining fish condition, comparing fish growth among areas, and as a complement to species specific reproduction and feeding studies [9-12]. Thus, if it is properly calculated, it can be very useful to fisheries management. Length weight relationship studies useful references for coastal water management and particularly marine fisheries [13].

The length -weight relationship of fish is usually assessed to yield the following informations:

To find out the mathematical relationship between the two characters, so that if one is known, the other could be computed.

To measure the variation from the general length weight relationship indicating fatness , general "well being" or gonad development [14] while the first category is studied under the term "length-weight relationship ", the second one is studied the term "condition".

The weight of a normal fish has a linear relationship with body length and generally the length-weight relationship could be expressed by a hypothetical cube law $\mathrm{w}=\mathrm{cl}^{3}$ where " $\mathrm{W}$ " is the weight. " $\mathrm{L}$ " length and "C"is a constant. This formula holds good to an ideal fish which maintains the same shape as it grows. However it is not always true Most of the fishes change their shape and form as they grow and so the exponent value may be altered [15]. Consequently, the hypothetical formula can be modified as $\mathrm{W}=\mathrm{al}^{\mathrm{n}}$ where "W" and " $\mathrm{L}$ " are weight and length respectively. "a" is a constant equivalent to "c" and " $\mathrm{n}$ " is another constant to be calculated empirically i.e, from the data however, it has been observed that there is no significant 
variation from the isometric growth $(n=3)$ [16]. The value of " $n$ " is normally between 2.5 and $4.0[17,15]$ but for an ideal fish $\mathrm{n}=3$.

The length-weight relationship studies (LWR) is an important tool in fish biology, physiology, ecology and fisheries assessment [18]. It can be used for converting lengths into biomass, determining fish condition, comparing fish growth among areas, and as a complement to species specific reproduction and feeding studies [19]. Thus, if it is properly calculated, it can be very useful to fisheries management. Length weight relationship studies useful references for coastal water management and particularly marine fisheries [20].

\section{MATERIALS AND METHODS}

Length-weight analysis for specimen comprising 494 males, 515 females and indeterminants of G. minuta, collected from Tuticorin fish landing centre was made to assess the relationship between the variables. Total length of the fish was measured in $\mathrm{cm}$ from the tip of snout to the end of the caudal fin and the weight was measured in gms upto 0.001 accuracy. Specimens with broken tail tips were not considered. Weight was measured after the removal of moisture and dirt. This observation was made for a period of one year from January to December 1989

The parabolic equation $\mathrm{W}=\mathrm{aL}^{\mathrm{n}}$ is expressed in logarithmic form as

$\log \mathrm{W}=\log \mathrm{a}+\mathrm{n} \log \mathrm{L}$

i.e., $y=a+b x$

Where,

$\mathrm{a}=\log \mathrm{a}$

$\mathrm{b}=\log \mathrm{n}$

$\mathrm{y}=\log \mathrm{w}$ and

$\mathrm{x}=\log \mathrm{L}$, which is linear relationship between $\mathrm{y}$ and $\mathrm{x}$. This linear equation was fitted separately for male, female and indeterminants and the estimates of parameters " $a$ " and " $b$ " for each category were obtained by the method of least squares.

The correlation co- efficient (" $r$ " values) were checked with " $t$ " test by using following formula

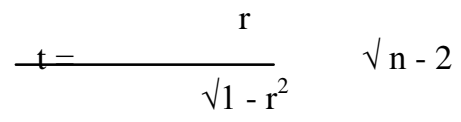

\section{Analysis of covariance was performed to understand the significance of regression co-efficient}

\section{RESULTS AND DISCUSSION}

The regression lines of male, female and indeterminants of G. minuta show a linear relationship between these two variables (length and weight). The correlation co-efficient (" $r$ " values) of male, female and indeterminants were found to be 0.9750 ( $\mathrm{p}<0.001), 0.9800(\mathrm{p}<0.001)$ and $0.8931(\mathrm{p}<0.001)$ respectively. The exponent ("b") values of male female and indeterminants were $2.95,3.07$ and 2.55 respectively. Then " $t$ " test was performed to test the significance of " $r$ " value. The "r" values were found to be highly significant this result giving evidence that the weight increased proportionately to an increase in the length of the fish. It can be noticed from the figures $2-4$, that $6 \mathrm{~b}$ the points are very close to the regression line indicating a close relationship between length and weight the linear equation fitted for male, female and indeterminants separately are given below:

$\begin{array}{lrl}\text { Male } & \log \mathrm{W}=-1.7812+2.9482 \log \mathrm{L} . \\ \text { Female } & \log \mathrm{M}=-1.9034+3.0775 \log \mathrm{L} . \\ \text { Indeterminants } & \log \mathrm{W}=-1.5696+2.5534 \log \mathrm{L} .\end{array}$

In order to understand the difference in regression co-efficient of male, female and indeterminants, analysis covariance was employed as followed by, [14], [21], [22], [23], [24], and [25]. The results are given in tables 1-3. Significant difference could be observed. Analysis of covariance was performed again, in order to find out the differences in regression coefficient between male and female and between male and indeterminants and similarly between female and indeterminants. The result is provided in Table 4-9 No significant differences were noted between male and female. But " $F$ " values observed for male and indeterminants and between female and indeterminants were found to be significant. The "b" value was found to be around " 3 " for the pooled data of male and female. The regression line fitted for the pooled data of male and female ids given below.

$$
\log W=1.85156+3.02302 \log \mathrm{L}
$$


Table 1: Sum of Squares and products of length-weight data of male, female and indeterminants of Gazza minuta

\begin{tabular}{|l|c|c|c|c|c|c|}
\hline \multicolumn{1}{|c|}{ Groups } & $\mathbf{N}$ & $\mathbf{S x}$ & $\mathbf{S y}$ & $\mathbf{S x}^{\mathbf{2}}$ & $\mathbf{S y}^{\mathbf{2}}$ & $\mathbf{S x y}$ \\
\hline Male & 494 & 462.2485 & 482.8910 & 434.0524 & 485.8831 & 456.3192 \\
\hline Female & 515 & 486.7018 & 517.5774 & 462.3298 & 543.5518 & 496.4353 \\
\hline Indeterminants & 84 & 52.5799 & 2.4135 & 33.5952 & 5.6504 & 3.2540 \\
\hline
\end{tabular}

$\mathrm{N}=$ Number of fish

Sx, sy = sum of logarithmic values of length and weight respectively

$\mathrm{Sx}^{2}, \mathrm{sy}^{2}, \mathrm{sxy}=$ sum of squares and products.

Table 2: corrected sum of squares and products of length-weight data co-efficient of allometry and deviation from the regression

\begin{tabular}{|l|c|c|c|c|c|c|c|}
\hline & \multicolumn{3}{|c|}{ Sum of squares and products } & \multicolumn{3}{c|}{ Errors of estimate } \\
\hline \multicolumn{1}{|c|}{ Groups } & df & $\mathbf{X}^{\mathbf{2}}$ & $\mathbf{x y}$ & $\mathbf{Y}^{\mathbf{2}}$ & $\mathbf{b}$ & $\mathbf{\text { df }}$ & \multicolumn{1}{c|}{ SS } \\
\hline Male & 493 & 1.5146 & 4.4657 & 13.8513 & 2.9482 & 492 & 0.6845 \\
\hline Female & 514 & 2.3713 & 7.2977 & 23.3841 & 3.0775 & 513 & 0.9253 \\
\hline Indeterminants & 83 & 0.6827 & 1.7433 & 5.5810 & 2.5534 & 82 & 1.1294 \\
\hline Total & 1090 & 4.5686 & 13.5067 & 42.8164 & 8.5791 & 1087 & 2.7392 \\
\hline
\end{tabular}

$\mathrm{df}=$ degrees of freedom, $\mathrm{b}=$ regression coefficient

$\mathrm{SS}=$ sum of squares

Table 3: Analysis of covariance for testing differences of regression of $\log W$ and $\log L$ between male and female and indeterminants of Gazza minuta

\begin{tabular}{|c|c|c|c|c|c|}
\hline Source of variation & df & Sum of squares & Mean squares & Observed F & $5 \% \mathrm{~F}$ \\
\hline
\end{tabular}

\footnotetext{
*significant
}

Table 4: Corrected sum of squares and products of length-weight data co-efficient of allometry and deviation from the regression for male and female

\begin{tabular}{|l|l|l|l|l|l|l|l|}
\hline & \multicolumn{3}{|c|}{ Sum of squares and products } & \multicolumn{3}{c|}{ Errors of estimate } \\
\hline \multicolumn{1}{|c|}{ Groups } & \multicolumn{1}{|c|}{$\mathbf{d f}$} & \multicolumn{1}{|c|}{$\mathbf{X}^{\mathbf{2}}$} & \multicolumn{1}{c|}{$\mathbf{Y}^{\mathbf{2}}$} & \multicolumn{1}{c|}{ b } & df & SS \\
\hline Male & 493 & 1.5146 & 4.4657 & 13.8513 & 2.9482 & 492 & 0.6845 \\
\hline Female & 514 & 2.3713 & 7.2977 & 23.3814 & 3.0775 & 513 & 0.9253 \\
\hline Total & 1007 & 3.8859 & 11.7634 & 37.2327 & & 1005 & 1.6098 \\
\hline
\end{tabular}

$\mathrm{df}=$ degrees of freedom, $\quad \mathrm{b}=$ regression coefficient

$\mathrm{SS}=$ sum of squares

Table 5: Analysis of covariance for testing differences of regression of $\log W$ and $\log L$ between male and female

\begin{tabular}{|c|c|c|c|c|c|}
\hline Source of variation & df & Sum of squares & Mean squares & Observed F & 5\% F \\
\hline Deviation of variation & 1005 & 1.6098 & 0.016 & $1.9375^{*}$ & \\
\hline $\begin{array}{c}\text { Diffrence between } \\
\text { regressions }\end{array}$ & 1 & 0.0127 & 0.0127 & & \\
\hline Deviation from total & 1006 & 1.6225 & 0.0143 & & \\
\hline
\end{tabular}

*Non -significant

Table 6: Corrected sum of squares and products of length-weight data co-efficient of allometry and deviation from the regression for male and indeterminants

\begin{tabular}{|l|c|c|c|c|c|c|c|}
\hline & \multicolumn{3}{|c|}{ Sum of squares and products } & \multicolumn{3}{c|}{ Errors of estimate } \\
\hline \multicolumn{1}{|c|}{ Groups } & df & $\mathbf{X}^{\mathbf{2}}$ & $\mathbf{x y}$ & $\mathbf{Y}^{\mathbf{2}}$ & $\mathbf{b}$ & $\mathbf{\text { df }}$ & $\mathbf{S S}$ \\
\hline Male & 493 & 1.5146 & 4.4657 & 13.8513 & 2.9482 & 492 & 0.6845 \\
\hline indeterminants & 83 & 0.6827 & 1.7433 & 5.5810 & 2.5534 & 82 & 1.1294 \\
\hline
\end{tabular}




\begin{tabular}{|l|c|c|c|c|c|c|c|}
\hline Total & 576 & 2.1973 & 6.209 & 19.4323 & & 574 & 1.8139 \\
\hline
\end{tabular}

$\mathrm{df}=$ degrees of freedom, $\mathrm{b}=$ regression coefficient

$\mathrm{SS}=$ sum of squares

Table 7: Analysis of covariance for testing differences of regression of $\log W$ and log $L$ between male and indeterminants

\begin{tabular}{|l|l|l|l|l|l|}
\hline \multicolumn{1}{|c|}{$\begin{array}{c}\text { Source of } \\
\text { variation }\end{array}$} & Sum of squares & Mean squares & Observed F & 5\% F \\
\hline $\begin{array}{l}\text { Deviation of } \\
\text { variation }\end{array}$ & 574 & 1.8139 & 0.00316 & $23.196^{*}$ & 2.99 \\
\hline $\begin{array}{l}\text { Diffrence between } \\
\text { regressions }\end{array}$ & 1 & 0.0733 & 0.0733 & & \\
\hline $\begin{array}{l}\text { Deviation from } \\
\text { total regression }\end{array}$ & 575 & 1.8872 & 0.07646 & & \\
\hline
\end{tabular}

*significant

Table 8: corrected sum of squares and products of length- weight data, co-efficient of allometry and deviation from regression for female and indeterminants.

\begin{tabular}{|c|c|c|c|c|c|c|c|}
\hline \multirow[b]{2}{*}{ Groups } & \multicolumn{4}{|c|}{ Sum of squares and products } & \multicolumn{3}{|c|}{ Errors of estimate } \\
\hline & df & $\mathbf{X}^{2}$ & $\mathbf{x y}$ & $\mathbf{Y}^{2}$ & b & df & SS \\
\hline Female & 514 & 2.3713 & 7.2977 & 23.3841 & 3.0775 & 513 & 0.9253 \\
\hline indeterminants & 83 & .6827 & 1.7433 & 5.5810 & 2.5534 & 82 & 1.1294 \\
\hline
\end{tabular}

$\mathrm{df}=$ degrees of freedom $\quad \mathrm{b}=$ regression co-efficient $\quad \mathrm{SS}=$ sum of squares

Table 9: Analysis of covariance for testing differences of regression of $\log W$ and $\log L$ between female and indeterminants

\begin{tabular}{|c|c|c|c|c|c|}
\hline Source of variation & df & Sum of squares & Mean squares & Observed F & 5\% F \\
\hline Deviation of variation & 595 & 2.0547 & 0.00345 & 0.1456 & \\
\hline $\begin{array}{c}\text { Diffrence between } \\
\text { regressions }\end{array}$ & 1 & 0.1456 & 0.14905 & & \\
\hline $\begin{array}{c}\text { Deviation from total } \\
\text { regression }\end{array}$ & 596 & 2.2003 & & \\
\hline
\end{tabular}

\footnotetext{
*significant
}

From the results it is suggested that the growth in male and female and indeterminants shows linear relationship between length and weight .The weight increases with increase in length. But in indeterminants, the weight increase seems to be less than that of the length, when compared with that of the mature ones. [26] observed the weight differences between male and female in L. bindus .[27] suggested that weight of male seems to be less than that of the female in L. dussumieri [28] and [29] have not considered the sexes separately while studying such relationship. However, [24] found significant "F" values for male and female of Thryssa dussumieri along Pakistan waters. Recently (1986) Hussain who has studied length -weight relationship of a culpied fish Ilisha melastoma suggested that the cubic law holds good and the equation $\mathrm{W}=\mathrm{al}^{3}$ may be the suitable one. In $G$. minuta also the cubic law was found to be the suitable one, particularly for adults.

\section{CONCLUSION}

Present study showed that toothed pony fishes community in the tuticorin fishing harbor contributed one of the major by catch composition in the trawler operations. The rate of exploitation on pony fish community in the tuticorin coastal water is believed at crucial stage of which can result in recruitment overfishing phenomena.

\section{ACKNOWLEDGEMENT}

Authors would like to thank Department of Zoology V. O Chidambaram College for providing all facility 
Authors declare that there is no conflict of interest

\section{CONFLICT OF INTEREST}

\section{REFRENCES}

[1] Mahadevan, S. "Report on the" kaaral "leiognathus spp. and Gazza minuta fishery of Rameshwaram Island in the gulf mannar and palk bay". Proc $4^{\text {th }}$ Indian sci .cong .part III abstract no.91, 1958.

[2] Jayabalan, N. A. "New species of Silver belly, Gazza shettyi (Pisces:leiognathidae) from the Bay of Bengal”. Matsya. Vol.11: pp.42-45, 1985.

[3] Sita Rami Reddi, P. "Studies on the osteology of silver bellies Leiognathus splendens and Gazza minuta”. Indian J. Fish, Vol.31, Issue.1, pp.4760, 1984

[4] Ranisingh, and P.K .Talwar. "On the little known pony fish, Gazza achlamys Jordon and starks (pisces :leiognathidae) in the Indian waters". Curr. Sci, Vol.23, Issue.47, pp930-931, 1978.

[5] Jayabalan n. and k. Ramamoorthi. "Determination of age and growth in the toothed pony fish Gazza minuta (bloch) from porto nova waters, Mahasagar - bulletin”. National Ins. Oceano, Vol. 19, Issue.3, pp.217 -220, 1986.

[6] Jayabalan, N. and K. Ramamoorthi. "Food and feeding habits of the silverbelly, Gazza minuta (bloch) in porto nova waters".Indian. J.mar. sci, Vol.14, pp.110-112, 1985.

[7] Jayabalan, N. "Reproductive biology of the pony fish, Gazza minuta (bloch) from porto novo East coast of India". Indian. J.mar. Sci, Vol.17, pp.51 -54, 1988.

[8] Oscoz J., Campos F. and Escala M.C. “Weight-length relationships of some fish species of the Iberian Peninsula”. J. Appl Ichthyol, Vol.21, Issue.1, pp.73-74, 2005.

[9] Petrakis G. and Stergiou K.I. “Weight-length relationships for 33 fish species in Greek waters”. Fisheries Res, Vol.21, Issue.3-4, pp.465-469, 1995.

[10] Koutrakis E.T. and Tsikliras A.C. "Length-weight relationships of fishes from three northern Aegean estuarine systems (Greece)". J. Appl. Ichthyol, Vol.19, Issue.4, pp.258-260, 2003.

[11] Froese R. and Cube law. "Condition factor and weight-length relationships: history, meta-analysis and recommendations". Journal of Applied Ichthyology, Vol.22, Issue.4, pp.241-253, 2006.

[12] Froese R.A.C., Tsikliras and Stergiou K.I. "Editorial note on weight-length relations of fishes". Acta Ichthyologica et Piscatoria, Vol.41, Issue.4, pp.261-263, 2011.

[13] Muddula Krishna N., Govinda Rao V. and Venu D. "Length-Weight relationships for some rock pool fishes off Visakhapatnam, east coast of India, Int. J. Fish”. Aquatic. Studies, Vol.2, Issue.3, pp.5-6, 2014.

[14] Le Cren, C. D. "The length -weight relationship and seasonal cycle in gonad weights and condition of the perch Perca fluviatilus". J. anim. Ecol, Vol.20, pp.200- 219, 1951.

[15] Martin,W. R. "The mechanism of environmental control of body from in fishes". Univ. Toronto stud Biol, Vol.70, pp.1-91, 1949.

[16] Beverton, R.J.H. and S.H. Holt. “On the dynamics of exploited fish population”. Fish invest. London Ser, Vol.219, pp.533, 1957.

[17] Hile, R. "Age and growth of the cisco, Leucichthys artedi (Le Sueur) in the lakes of north eastern highlands, Wisconsin. Bull”. U.S. Bur. Fish, Vol.48, Issue.211-317, 1936.

[18] Oscoz J., Campos F. and Escala M.C., "Weight-length relationships of some fish species of the Iberian Peninsula”. J. Appl Ichthyol., Vol.21, issue.1, pp.73-74, 2005

[19] Petrakis G. and Stergiou K.I., “Weight-length relationships for 33 fish species in Greek water” Fisheries Res, Vol.21, Issue.3-4, pp.465-469, 1995.

[20] Koutrakis E.T. and Tsikliras A.C., "Length-weight relationships of fishes from three northern Aegean estuarine systems (Greece)". J. Appl. Ichthyol, Vol.19, Issue.4, pp.258-260, 2003.

[21] Arora, H.L. "A contribution to the biology of silver belly, leiognathus splendens (cuv)sec II;Proc". Indo -pacific fish.Coun, pp.75-80, 1951.

[22] James, P.S.B.R. "The ribbon fishes of the farming trichiuridea of India”. Memoir I marine biological association of India, pp226, 1967.

[23] Rangarajan, k. "Length-weight relationship in the snapper, lutianus kasmira (Forskal)". Indian. J.Fish, Vol.20, Issue.2, pp.295-308, 1973.

[24] Hoda, S. M. S. "Reproductive biology and length-weight relationship of thryssa dussmieri (val.) of the Pakistan coast”. J. mar. Biol. Ass. India, Vol.18, pp.272-287, 1976.

[25] Venkataramani, V.K. "Bio systematic studies in carangid fishesof porto novo coast (perciformes: carangidae)”. Ph.D. Thesis, Annamalai University. India, pp.290, 1979.

[26] Balan,V. "Biology of the silver belly leiognathus bindus (val.) of the Calicut coast". Indian, Vol.10, pp.1, pp.118-134, 1963.

[27] James, P.S.B.R.and M. Badrudeen. "Biology and fishery of the silverbelly, leiognathus dussumieri (Valenciennes) from the Gulf of mannar". Indian .J.Fish, Vol.28, Issue.1-2, pp.154-182, 1981.

[28] Venkatraman, G. "Studies on some aspects of the biology of the commonanchvoy, thrissocles mystax (bloch and schneider)". Indian. J. Fish, Vol.3, Issue.311- 333, 1956.

[29] Babu Rao, M. “Studies on the Cluppied Fishes of Godavari Estuary”. Ph.D. Thesis Andhra Univ. (India), pp.223, 1962.

\section{Author Profile}

Ms. S. Puvaneswari pursed B.Sc from Sri Parasakthi College for Women, Courtallam, Manonmaniam Sundaranar University, 1986. She pursed M.Sc and Ph.D from Annamalai University Chidambaram Tamil Nadu, India in 1988, 2008. She pursed M.Phil from Department of Zoology V.O, Chidambaram College Tuticorin in 1990. She is currently Assistant Professor in Department of Zoology Annamalai University, Tamil Nadu India. Her main research work focuses on Fish Toxicology. She is having 19 years of Research and teaching experience. 